\title{
Water Relations of Field-grown Quercus virginiana Mill. from Preharvest through Containerization and 1 Year into a Landscape
}

\author{
R.C. Beeson, Jr. \\ Central Florida Research and Education Center, Institute of Food and Agricultural Sciences, \\ University of Florida, 2700 East Celery Avenue, Sanford, FL 32771-9608
}

Additional index words. live oak, fabric container, container production, urban forestry, landscape physiology, root pruning

\begin{abstract}
Large ( $\approx 5 \mathrm{~m}$ high) Quercus virginiana Mill. (live oak) trees produced in 0.64-m-diameter in-ground fabric containers were root pruned or not root pruned inside containers before harvest. Harvested trees were grown in two sizes of polyethylene containers for 10 months, then transplanted into a landscape. Water potential $\left(\psi_{T}\right)$ of small branches ( $<4 \mathrm{~mm}$ in diameter) was measured diurnally during containerization and for 1 year in the landscape. Root pruning had no influence on postharvest survival. Neither root pruning nor container size affected tree water status during containerization or in the landscape. All surviving trees recovered from transplant shock following harvest after 16 weeks in a container, independent of treatment. In the landscape, 35 weeks of daily irrigation were required before dusk $\psi_{\mathrm{T}}$ declined to within $0.1 \mathrm{MPa}$ of predawn values, a result indicating alleviation of transplant shock. Trunk growth rate during containerization was highest in larger containers. However, in the landscape, root pruning and small containers were associated with higher trunk growth rate. Tree water status during containerization and in the landscape is discussed.
\end{abstract}

Due to the adverse impact of several freezes in the early 1980 s on citrus groves, many groves in Florida were replanted with shade trees. Most groves used in-ground fabric containers (Whitcomb, 1985) since they were on coarse, excessively drained sandy soils, a condition that made spade or ball and burlap operations difficult. By 1989, lack of information and improper handling resulted in the death of many transplanted trees. This reduced marketability and forced farms to containerize harvested fabric-grown trees by removing the fabric containers from root balls and transplanting the trees into large containers filled with a pine bark-based medium. Trees were allowed to increase canopy density and regenerate their roots to fill the containers before marketing. There were no standard ratios of container to root-ball volumes in the industry. The container size used depended on cost, tree caliper, and producer preference. Trees of similar size and age could be found growing in containers differing in volume by $100 \%$. Significant tree loss, especially with Quercus virginiana (live oak), occurred at most tree farms during containerization, usually within a few weeks after field harvest. For surviving trees, the effect of different container volumes for similar sized trees transplanted into landscapes was unknown.

In some field nurseries, the practice of repeated preharvest root pruning is considered essential for quality postharvest trees (Watson, 1986). In Florida, root pruning is beneficial only if practiced within 6 months of harvest (Gilman and Kane, 1990). Root pruning citrus trees in Florida stimulated $\approx 25 \%$ increase in fibrous roots after 4 months (Castle, 1983). Manual root pruning is not practiced for in-ground fabric container production because physical constraints of the fabric results in self-pruning (Whitcomb, 1985). However, species difficult to harvest from in-ground fabric con-

Received for publication 8 Feb. 1993. Accepted for publication 30 July 1993. Univ. of Florida Agricultural Experiment Stations Journal series no. R-02984. Use of trade names does not imply endorsement of products named nor criticism of similar ones not mentioned. The cost of publishing this paper was defrayed in part by the payment of page charges. Under postal regulations, this paper therefore must be hereby marked advertisement solely to indicate this fact.

${ }^{1}$ Assistant professor. tainers often develop roots with diameters $>50 \mathrm{~mm}$, which exit the fabric almost without constriction. Trees with such thick peripheral roots have fewer associated fine roots within the harvested ball and either die or remain qualitatively poor for several years (R.C. Beeson, unpublished data).

Trees grown in fabric containers and acclimatized to postharvest conditions usually have low-density canopies due to extensive leaf senescence during acclimatization (Beeson and Gilman, 1992). Such trees often must be held beyond sufficient root regeneration to develop acceptable canopy densities. Reductions in shoot growth after harvest are proposed due to inability of root systems to absorb sufficient water and nutrients for vigorous growth (Watson, 1985). More rapid shoot growth of Photinia Xfraseri liners in small vs. large containers was proposed due to a more rapid increase in root density, thus improving absorption of water and nutrients (Beeson, 1993). Although root constrictions reduce long-term shoot growth (Biran and Eliassaf, 1980; Keever and Cobb, 1987), before root restriction, shoot growth in small containers can be greater than in large containers (Richards and Rowe, 1977; Tschaplinski and Blake, 1985).

The present study was initiated in 1989 to study influences of root pruning and container to root-ball volume ratios of fabric-grown trees on plant physiology from harvest through containerization and into a landscape site, with emphasis on plant water status. Manual root pruning was hypothesized to improve postharvest survival of difficult species. Containerizing with a small container to root-ball volume ratio was hypothesized to increase the rate of canopy re-leaf. Effects of root pruning and container to root-ball volume ratios were further evaluated after transplanting to study their influence on tree establishment. Live oak represents the highest production acreage in Florida and is the most difficult species to successfully harvest from in-ground fabric containers.

\section{Materials and Methods}

Live oak seedlings were transplanted in Fall 1985 from 3.8-liter containers into 0.64-m-diameter fabric containers (Root Control, 
Stillwater, Okla.) in an excessively drained fine sand (Astatula fine sand series) and backfilled with a 50:50 mixture of native soil and 6 pine bark : 3 Florida peat moss : 1 sand medium. Irrigation was by overhead sprinklers ( $5 \mathrm{~m}$ high) and fertilizer was uniformly broadcast using a $10 \mathrm{~N}-4.4 \mathrm{P}-8.3 \mathrm{~K}$ granular at unknown annual rates. Trees were $\approx 5 \mathrm{~m}$ high with $\approx 100-\mathrm{mm}$ trunk diameters at 0.15 $\mathrm{m}$ above the soil at harvest.

On 9 Oct. 1989, one-half of 32 randomly selected trees were assigned to be manually root pruned and were pruned 9 days later with a sharp spade. The spade was driven along the inside surface through a container bottom on east and west sides, cutting $\approx 50 \%$ of the circumference.

Shoot water potential $\left(\psi_{\mathrm{T}}\right)$ was measured weekly before dawn beginning 11 Oct. 1989 on leafy branches (<4 $\mathrm{mm}$ in diameter) collected $<2 \mathrm{~m}$ above ground with a pressure chamber as described previously (Beeson, 1992). Measurements became biweekly after 6 weeks until harvest on 19 Dec. 1989. Immediately after being dug, trees were supported upright with root-ball irrigation (46 liters/h per tree, spot spitters; Roberts Irrigation Products, San Marcos, Calif.) and continuous overhead misting during the day in a holding area. Trees were transported $115 \mathrm{~km}$ to the research facility 1 or 2 days later and held in a similar area with a similar water regime. Overhead misting was gradually reduced to zero by 23 Jan. 1990, a time period consistent with industry practice. Six live oaks (75-mm trunk diameter at $0.15 \mathrm{~m}$ ) were transported $20 \mathrm{~km}$ to the research facility on 28 Dec. 1989 and treated as above. These trees were collected 6 months earlier with a 60-cm spade, placed in treated burlap-lined baskets and lifted several times after collection.

Containerization phase. On 23 and 24 Jan. 1990, fabric containers were removed and trees were transplanted into 133- or 247-liter polyethylene containers (Lerio Corp., Kissimmee, Fla.). Eight trees from each root-pruning treatment were randomly potted into each container size. Media consisted of 3 pine bark : 1 Florida peat moss : 1 coarse sand (by volume) amended with micronutrients (Micromax, Grace-Sierra Chemical Co., Malpitas, Calif.) at $0.87 \mathrm{~kg} \cdot \mathrm{m}^{-3}$. Spade-dug trees exhibited no symptoms of transplant shock and were transplanted into 247-liter containers to serve as control trees.

After transplanting, irrigation occurred for $15 \mathrm{~min}$ at 0600 , 0930, 1200, 1500, and 1900 HR daily with two emitters per container (64 liter $\cdot \mathrm{h}^{-1}$, black spot spitters). Irrigation frequency was reduced to 0600,1100 , and $1600 \mathrm{HR}$ on 8 Feb. 1990 and changed to 0800,1200 , and 1600 HR on 8 June 1989. Trees were fertilized with controlled-release fertilizer (Osmocote 14N-6.0P11.6K; Grace-Sierra Chemical Co.) at $300 \mathrm{~g}$ per container in mid-February 1990 and refertilized with Osmocote 18N-2.6P9.9K with the same amount on 9 May 1990.

After transplanting, predawn $\psi_{\mathrm{T}}$ was measured weekly on trees with available leaves. Leaf senescence occurred on all but control trees due to abnormal subfreezing temperatures on 24 Dec. and excessive water stress. Predawn $\psi_{\mathrm{T}}$ measurements became consistent with diurnal measurements after 6 weeks.

Eight weeks after containerization, sufficient new shoot growth was present on a subset of three trees per treatment and control for biweekly diurnal measurements of $\psi_{\mathrm{T}}$. Diurnal measurements began before dawn with $\psi_{\mathrm{T}}$ measured about every $2 \mathrm{~h}$ through 1600 HR. Branches were sampled from the sunlit canopy periphery within $1.5 \mathrm{~m}$ above a root-ball surface. Morning measurements were taken from the east side, progressing in afternoon to the west side. Diurnal measurement occurred monthly after May. Predawn $\psi_{\mathrm{T}}$ was measured on all trees with available leaves until tree death was ascertained. Twelve and 16 weeks after potting ( 2 and 30 May 1990 , respectively), stomatal conductance $\left(g_{s}\right)$ was measured on the same branch used for $\psi_{\mathrm{T}}$ measurement with a steady-state porometer (LI-1500; LI-COR, Lincoln, Neb.).

Landscape phase. On 8 Nov. 1990, the 15 trees on which diurnal $\psi_{\mathrm{T}}$ was measured during containerization were transported $65 \mathrm{~km}$ to another research facility and transplanted into an excessively drained fine sand (Apopka fine sand series). Trees were planted on 3.7-m centers into a sodded field (bahia) in a strip $2 \mathrm{~m}$ wide previously treated with $N$-(phosphonomethyl)glycine (glyphosate). Planting holes were $\approx 1 \mathrm{~m}$ in diameter and generally 0.15 to $0.25 \mathrm{~m}$ larger than a root ball. Holes were backfilled with native soil and trees were anchored with three lines.

Tree stakes with $360^{\circ}$ low-volume emitters $\left(76\right.$ liters $\cdot \mathrm{h}^{-1}$; model DS-16; Rainbird, Glendora, Calif.) irrigating a circle $\approx 1.2 \mathrm{~m}$ in diameter were placed on opposite sides of a tree and positioned so water reached, but did not wet, the trunk. Most of a root ball and areas extending $\leq 0.6 \mathrm{~m}$ beyond the ball edge on either side were irrigated. Irrigation rates of 9.6 liters $/ 10 \mathrm{~mm}$ trunk diameter (at $0.15 \mathrm{~m}$ ) per day (Beeson, 1991) resulted in 103 liters/day per tree. Volume was applied in split applications at 0800 and $1400 \mathrm{HR}$ the first 2 months and once per day at $0800 \mathrm{HR}$ thereafter. On 6 Sept. 1991, irrigation was reduced to alternating days and decreased to 77 liters per application. Controlled-release fertilizer (Osmocote $18 \mathrm{~N}-2.6 \mathrm{P}-10 \mathrm{~K})$ was hand broadcast $\approx 4 \mathrm{~m}$ around a trunk on 12 Apr. and 9 July at $450 \mathrm{~g} /$ tree. Weeds were controlled with glyphosate, and lanes between rows were mowed.

After transplanting, $\psi_{\mathrm{T}}$ was measured diurnally from before dawn until after sunset (dusk) at $\approx 2$-h intervals for 1 year. Measurements occurred biweekly the first month and were reduced to every 6 to 8 weeks after 8 weeks. At the beginning and end of each measurement interval of $\psi_{\mathrm{T}}$, instantaneous measurements of photosynthetic photon flux density (PPFD) and air temperature and relative humidity were recorded using a photometer (model LI-185B; LI-COR) and a hygrometer-thermometer (Fisher Scientific, Pittsburgh), respectively. All microclimate measurements were made in open areas to estimate above-canopy conditions. Irrigation was interrupted for 12 days beginning 20 Nov. 1991 to impose a dry-down phase. Diurnal $\psi_{\mathrm{T}}$ measurements were made 0 , 8 , and 12 days after irrigation was stopped. No rain occurred during this period.

Trunk circumference (at $0.15 \mathrm{~m}$ ) was measured periodically from 19 Dec. 1990 until 16 June 1992. Cumulative daily water stress $\left(\mathrm{S}_{\mathrm{Y}}\right)$ was calculated as described previously using $-0.05 \mathrm{MPa}$ as the maximum $\psi_{\mathrm{T}}$ measured (Beeson, 1992). Approximate vapor-pressure deficit was calculated as the difference between saturating vapor pressure and absolute vapor pressure at air temperature for each measurement. Leaf temperatures were assumed to be those of air. Cumulative PPFD and cumulative approximate vapor-pressure deficit (CAVP) were calculated by integrating areas under diurnal curves of PPFD and approximate vaporpressure deficit.

Data were analyzed separately for preharvest, container, landscape, and dry-down phases. Predawn $\psi_{\mathrm{T}}$, minimum $\psi_{\mathrm{T}}$, dusk $\psi_{\mathrm{T}}$, $\mathrm{S}_{\mathrm{Y}}, \mathrm{g}_{\mathrm{s}}$, and trunk circumference were analyzed as repeated measurements with a random design using a split plot, with treatments as the main plot and time as the subplot (Snedecor and Cochran, 1980). Trunk growth rates were calculated as the difference in circumference between measurement dates divided by weeks between measurements and analyzed by regression. Slopes of resulting regression equations were compared by single-degree-offreedom contrast (Snedecor and Cochran, 1980). Each surviving tree served as a replicate. Correlations of $S_{Y}$ with cumulative PPFD and CAVP and mean day temperature were calculated using SAS' linear regression (SAS Institute, Cary, N.C.). 


\section{Results and Discussion}

Root pruning did not significantly affect predawn $\psi_{\mathrm{T}}$ measured before harvest. Predawn $\psi_{\mathrm{T}}$ ranged from -0.05 to $-0.13 \mathrm{MPa}$ during the period (data not included). Trunk circumferences did not differ among treatments during the containerization or landscape phases (data not included). Trunk growth rates (mm circumference/week) were constant for root-pruned trees and trees in 133liter containers (Fig. 1). However, growth rates for control $(-0.19$ $\mathrm{mm} /$ week) and nonroot-pruned trees grown in 247-liter containers $(-0.25 \mathrm{~mm} /$ week) declined during the landscape phase.

Containerization phase. Survival was six unpruned and six pruned trees in 133-liter containers, and five unpruned and seven pruned trees in 247-liter containers. All control trees survived. In a related study of large live oaks, similar root pruning improved postdigging survival compared to nonpruned trees (Beeson and Gilman, 1992). In the present study, trunk diameters were within harvest specifications; whereas, in the other study, trunks were larger than recommended at harvest. Thus, root pruning in fabric containers is not beneficial when trees are harvested within specifications, but improves survival of oversized trees.

Predawn $\psi_{\mathrm{T}}$ of control trees was generally above $-0.2 \mathrm{MPa}$ during the first 15 weeks and was $-0.1 \mathrm{MPa}$ or higher thereafter (Fig. 2). Predawn $\psi_{\mathrm{T}}$ of surviving treatment trees ranged from 0.25 to $-2.9 \mathrm{MPa}$ during the first 16 weeks (Fig. 2). Control trees had higher predawn $\psi_{\mathrm{T}}$ initially and during weeks 10 to 15 and 30 and 34 weeks after potting than treatment trees. High variability during budbreak (weeks 3 to 8) precluded significant differences in predawn $\psi_{\mathrm{T}}$ among treatment and control trees during the second through the ninth week after potting.

$\mathrm{S}_{\mathrm{Y}}$ values for control trees were generally consistent and $\approx 4$ to 5.3 $\mathrm{MPa}^{-1}$ (Fig. 3). This consistency was somewhat due to limiting diurnal measurement periods from dawn to $1600 \mathrm{HR}$, thereby partially ignoring longer day lengths of summer. Treatment trees, relative to control trees, exhibited significantly higher $\mathrm{S}_{\mathrm{Y}}$ at 8 and 12 weeks after potting (Fig. 3). $\mathrm{S}_{\mathrm{Y}}$ values of treatment trees declined through the first 24 weeks, becoming consistent for all trees for the remainder of the containerization phase.

Stomatal conductance $\left(g_{s}\right)$ measurements of control trees (Table 1) confirmed their high water status calculated as low $S_{Y}$ values. Comparable mean $\mathrm{g}_{\mathrm{s}}$ values of $112 \mathrm{mmol} \cdot \mathrm{m}^{-2} \cdot \mathrm{s}^{-1}$ were reported for irrigated live oak seedlings (Messina and Duncan, 1993). Mean $g_{s}$ of control trees was much higher than those of 20 to $40 \mathrm{mmol} \cdot \mathrm{m}^{-2} \cdot \mathrm{s}^{-}$ ${ }^{1}$ measured for water-stressed oaks (Tenhunen et al., 1985; Weber and Gates, 1990). Transplant shock has been described as an extended period of water stress after transplanting caused by unfavorable shoot to root ratios (Kozlowski and Davies, 1975). Since water stress was not evident in control trees, water relation variables measured for these trees can be used to determine establishment and root regeneration of treatment trees.

During the first 16 weeks after potting, root regeneration was probably rapid, resulting in improved tree water status, as evidenced by higher predawn $\psi_{\mathrm{T}}$ (Fig. 2) and $\mathrm{g}_{\mathrm{s}}$ (Table 1) and lower $\mathrm{S}_{\mathrm{Y}}$ values (Fig. 3) and budbreak. In conifers, $\psi_{\mathrm{T}}$ increased proportional to root development (Grossnickle, 1988). For other tree species, root regeneration was associated with recovery to prepruned levels of photosynthesis, a result indicative of improved water status (Arnold and Struve, 1989; Geisler and Ferree, 1984). By 16 weeks after potting, water status and $\mathrm{g}_{\mathrm{s}}$ of pruned and unpruned trees were similar to those of control trees, a result indicating recovery from transplant shock, provided sufficient irrigation.

Root pruning had no measured effect on tree water status during containerization. Predawn $\psi_{\mathrm{T}}$ and $\mathrm{S}_{\mathrm{Y}}$ values were similar between

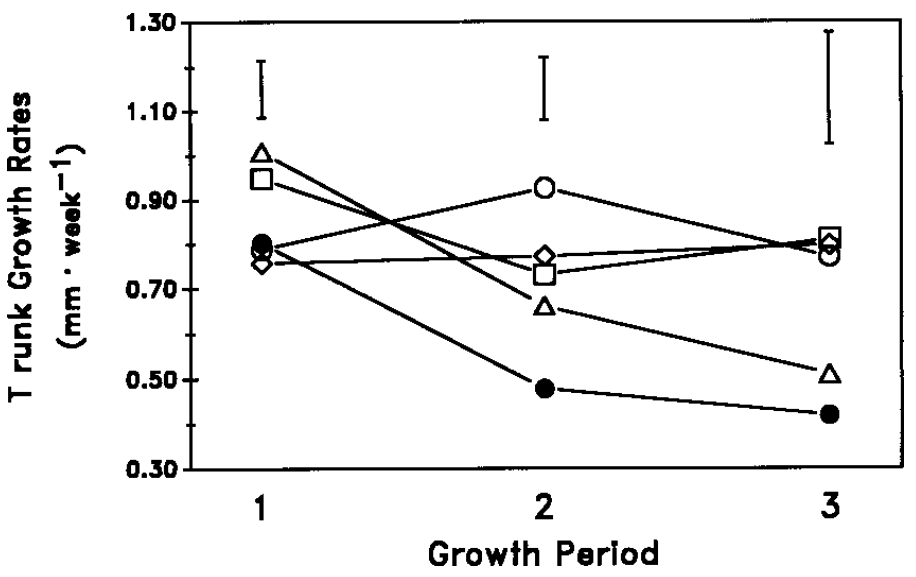

Fig. 1. Mean trunk circumference growth rates per period measured $0.15 \mathrm{~m}$ above the soil for control $(\bigcirc)$, unpruned small (UP-S; O), unpruned large (UP-L; $\Delta$ ), pruned small $(\mathrm{P}-\mathrm{S} ; \diamond)$, and pruned large $(\mathrm{P}-\mathrm{L} ; \square)$ containers. Trunk growth rates were calculated as the increase in circumference divided by the number of weeks within each period. Period 1 spans the containerization phase. Period 2 was growth during the first year in the landscape. Period 3 extends from 12 to 18 months after transplanting into the landscape. Means are of three tree replicates. Vertical bars indicate the mean SE for each period.

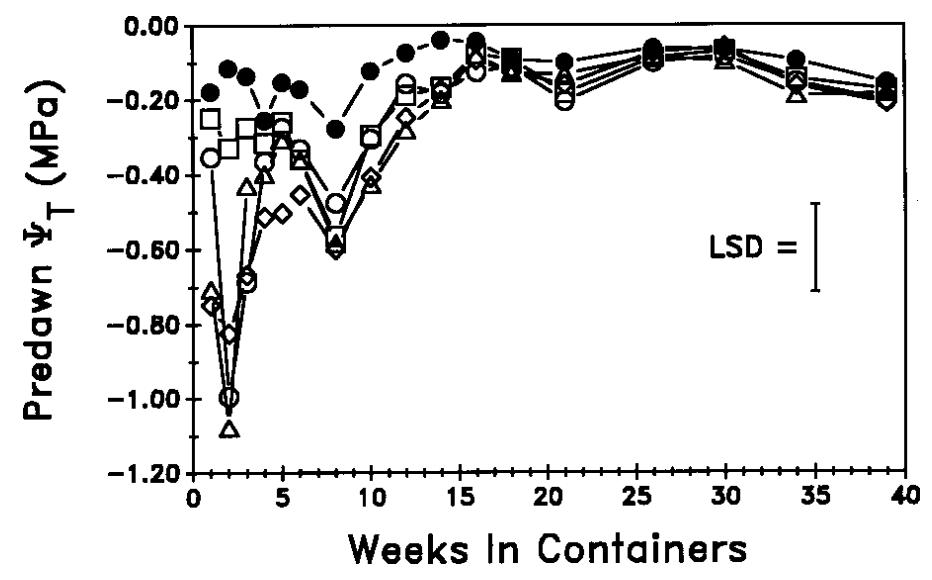

Fig. 2. Predawn water potentials measured during the containerization phase for control (O), unpruned small (UP-S; $\bigcirc)$, unpruned large (UP-L; $\Delta$ ), pruned small $(\mathrm{P}-\mathrm{S} ; \diamond)$, and pruned large $(\mathrm{P}-\mathrm{L} ; \square)$ containers. The vertical bar represents the $\mathrm{F}$ test protected LSD at $\alpha=0.05$.

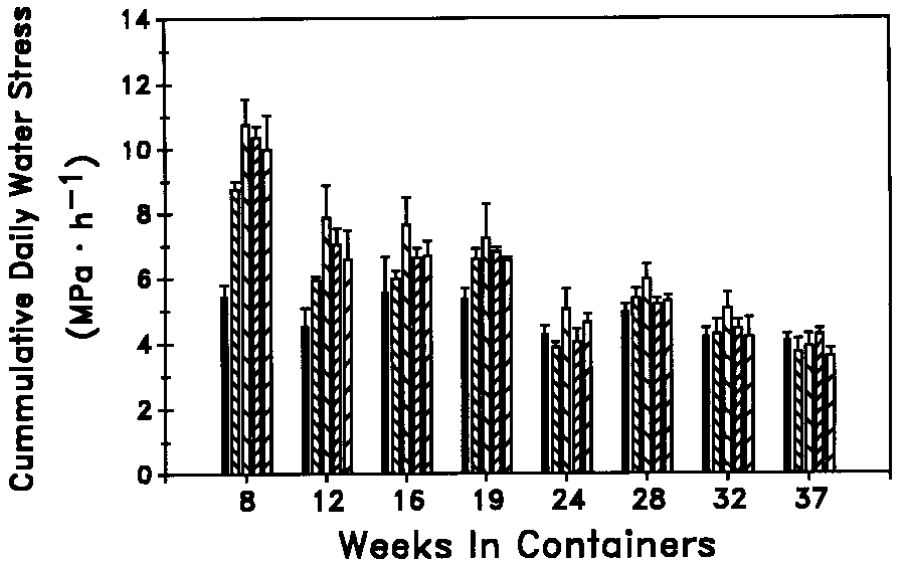

Fig. 3. Cumulative daily water stress $\left(\mathrm{S}_{\mathrm{Y}}\right)$ values calculated during containerization for control (solid), unpruned small (UP-S; narrow left diagonal), unpruned large (UP-L; wide left diagonal), pruned small (P-S, narrow right diagonal), and pruned large $(\mathrm{P}-\mathrm{L}$; wide right diagonal) containers. Each bar represents the mean of three trees, while the vertical lines represent the SEs. 
Table 1 . Mean daily stomatal conductance $\left(\mathrm{g}\right.$, in $\left.\mathrm{mmol} \cdot \mathrm{m}^{-2} \cdot \mathrm{s}^{-1}\right)$ and mean daily photosynthetic photon flux (PPFD, in $\mu \mathrm{mol} \cdot \mathrm{m}^{-1} \cdot \mathrm{s}^{-1}$ ) at the time of measurement for treatment and control trees used in diurnal water potential measurements 12 and 16 weeks after potting. PPFD and $g_{s}$ were measured at 0900, 1100, 1300, and $1500 \mathrm{HR}$. Daily means are the average of three trees measured at each time period.

\begin{tabular}{lccccr}
\hline & \multicolumn{2}{c}{ Week 12 } & & \multicolumn{2}{c}{ Week 16 } \\
\cline { 2 - 3 } \cline { 5 - 6 } Treatment $^{\mathrm{z}}$ & $\mathrm{g}_{\mathrm{s}}$ & PPFD & & $\mathrm{g}_{\mathrm{s}}$ & PPFD \\
\hline Control & $136 \mathrm{a}^{\mathrm{y}}$ & 429 & & $115 \mathrm{a}$ & 1105 \\
Unpruned, 133 liters & $124 \mathrm{ab}$ & 426 & & $105 \mathrm{a}$ & 1279 \\
Unpruned, 247 liters & $95 \mathrm{bc}$ & 583 & & $106 \mathrm{a}$ & 1185 \\
Pruned, 133 liters & $130 \mathrm{a}$ & 864 & & $125 \mathrm{a}$ & 1182 \\
Pruned, 247 liters & $71 \mathrm{c}$ & 637 & & $113 \mathrm{a}$ & 259
\end{tabular}

${ }^{\mathrm{z} T r e a t m e n t s ~ i n i t i a t e d ~ i n ~ t h e ~ c o n t a i n e r i z a t i o n ~ p h a s e . ~ T r e e s ~ w e r e ~ r o o t ~}$ pruned or not root pruned before harvest and transplanted into 133- or 247liter polyethylene containers.

${ }^{y}$ Means with the same letter are not significantly different $(\alpha=0.05)$ in $\mathrm{g}_{\mathrm{s}}$ columns based on mean separation using Fisher's protected LSD.

root-pruned and nonroot-pruned trees. However, differences between root-pruning treatments may have diminished because of the time under misting after digging. Preharvest root pruning of Pinus eliottii resulted in higher predawn $\psi_{\mathrm{T}}$ and lower $\mathrm{S}_{\mathrm{Y}}$ values compared to nonroot-pruned trees for 6 weeks after transplanting (Beeson and Gilman, 1992). Root pruning also reduced water stress after transplanting citrus, but the reduction was limited and short term (Castle, 1983).

Container size had no overall effect on tree water status during containerization. However, trunk growth rates (period 1; Fig. 1) of trees in large containers were greater during containerization than trees in smaller containers. Since trunk diameter of small trees is proportional to the photosynthetically active canopy (Grier and Waring, 1974) and root balls were similar, trunk growth rates suggest that decreasing the container to root-ball volume ratio may have impeded canopy re-leafing. Neither recovery time nor water status among treatments was significantly different $(\alpha=0.05)$, therefore, neither root pruning nor decreasing the container to rootball volume ratio reduced the period of transplant shock.

Landscape phase. Treatment effects and treatment $\times$ week interactions for predawn, minimum, or dusk $\psi_{\mathrm{T}}$ were not significantly different $(\alpha=0.05)$ in the landscape; however, differences between weeks were significant. Mean predawn $\psi_{\mathrm{T}}$ ranged from 0.05 to $-0.28 \mathrm{MPa}$ and consistently measured about $-0.1 \mathrm{MPa}$ after week 20 (Fig. 4). Although trees were well rooted and irrigated daily, 15 to 20 weeks were required for root exploration into the landscape to permit complete recovery from transpirational losses of the previous day.

Mean minimum $\psi_{\mathrm{T}}$ ranged from -0.48 to $-1.18 \mathrm{MPa}$ (Fig. 4) and, except for weeks 2 and 26, was above-0.8 MPa. Minimum $\psi$ usually occurred in mid-afternoon and was high for live oak at all dates. Water potentials above $-1.8 \mathrm{MPa}$ are not associated with significant declines in $\mathrm{g}_{\mathrm{s}}$ for live oak (Messina and Duncan, 1992; R.C. Beeson, unpublished data). For other xeric Quercus species, low $\mathrm{g}_{\mathrm{s}}$ was associated with a $\psi_{\mathrm{T}}$ of $-2.5 \mathrm{MPa}$ or lower (Tenhunen et al., 1985). High minimum $\psi_{\mathrm{T}}$ indicates that the irrigation scheme maintained trees at a high water status during the landscape phase.

Dusk $\psi_{\mathrm{T}}$ ranged from -0.13 to $-0.48 \mathrm{MPa}$ and was within 0.1 MPa of predawn $\psi_{\mathrm{T}}$ by week 34 and thereafter (Fig. 4). Dusk $\psi_{\mathrm{T}}$ measures the recovery ability from the current day's water demand, and may also indicate root exploration into a transplant site. In moist soils, large differences between dusk and predawn $\psi_{\mathrm{T}}$ occurred in recently transplanted trees with minimum root explo-

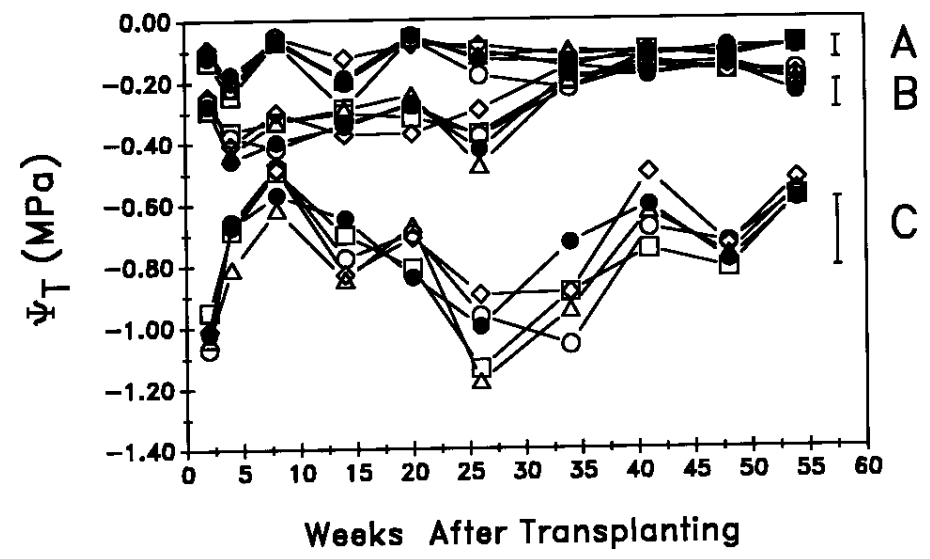

Fig. 4. Predawn (A), dusk (B), and minimum water potentials $(\mathbf{C})$ measured during the landscape phase for control ( ), unpruned small (UP-S; $\bigcirc)$, unpruned large $(\mathrm{UP}-\mathrm{L} ; \Delta)$, pruned small $(\mathrm{P}-\mathrm{S} ; \diamond)$, and pruned large $(\mathrm{P}-\mathrm{L} ; \square)$ containers. Means are based on three tree replicates. The vertical bars represent the $\mathrm{F}$ test protected LSD at $\alpha=0.05$ for each group of water potentials.

ration; whereas, small differences were measured in undisturbed trees and transplanted trees after roots had regenerated (unpublished data). In the landscape, differences between predawn and dusk $\psi_{\mathrm{T}}$ were within $0.1 \mathrm{MPa}$ by week 34 , a result implying sufficient root exploration to meet daily water demands under moist soil conditions.

$S_{Y}$ values were similar among treatments after transplanting, with values increasing and decreasing consistently with seasonal changes in day length, as exemplified by control trees (Fig. 5A; week $34=3$ July). Seasonal patterns of cumulative PPFD (Fig. 5B) and CAVP (Fig. 5C) were similar to those of $S_{y}$. Both microclimate measurements peaked at week 20 (26 Mar.), before the onset of the rainy season, with frequent cloud development in afternoons. Correlations between cumulative PPFD and $\mathrm{S}_{\mathrm{Y}}$ and CAVP and $\mathrm{S}_{\mathrm{Y}}$ were significant $(\alpha=0.01)$ for all treatments, with the highest correlation with control trees (Table 2). For all trees, (data not shown) CAVP had the strongest correlation with $\mathrm{S}_{\mathrm{Y}}\left(r^{2}=0.492 ; \alpha\right.$ $=0.01$ ), while the correlation with cumulative PPFD was weak but significant $\left(r^{2}=0.370 ; \alpha=0.05\right)$. The significant correlation of CAVP with $\mathrm{S}_{\mathrm{Y}}$ is interesting, considering that leaf temperature was assumed equivalent to that of the air and cumulative values were calculated from instantaneous measurements, which vary rapidly with passing clouds. Vapor-pressure deficits regulate $g_{s}$ under low to moderate water-stress conditions in many tree species (MaierMaercher, 1979; Whitehead et al., 1983) and have been strongly correlated with daily variation in stem $\psi_{\mathrm{T}}(\mathrm{McCutchan}$ and Schackel, 1992). In contrast to cumulative PPFD and CAVP, temperature on sampling days peaked at week 37 (Fig. 5D). Mean temperature correlations with $S_{Y}$ were very weak or not significant (Table 2). Although temperature measurements help characterize a landscape site's microclimate, independently they are of little value in quantifying a site's influence on water stress.

During the dry-down phase (Nov. 1991), no differences among treatments for any $\psi_{\mathrm{T}}$ variables measured or $\mathrm{S}_{\mathrm{Y}}$ were found. Mean predawn $\psi_{\mathrm{T}}$ declined from -0.09 to $-0.12 \mathrm{MPa}$, dusk $\psi_{\mathrm{T}}$ declined from -0.2 to $-0.55 \mathrm{MPa}$, minimum $\psi_{\mathrm{T}}$ declined from -0.56 to -1.31 $\mathrm{MPa}$, and mean $\mathrm{S}_{\mathrm{Y}}$ values increased from 3.9 to $11.5 \mathrm{MPa} \cdot \mathrm{h}^{-1}$ on days 0 and 12, respectively. Irrigation was withheld to evaluate differences in canopy to water-absorbing root area among treatments. A high canopy to root area ratio would have shown water stress more quickly and perhaps to a higher degree than a more favorable ratio. After a year in the landscape, the canopy to 

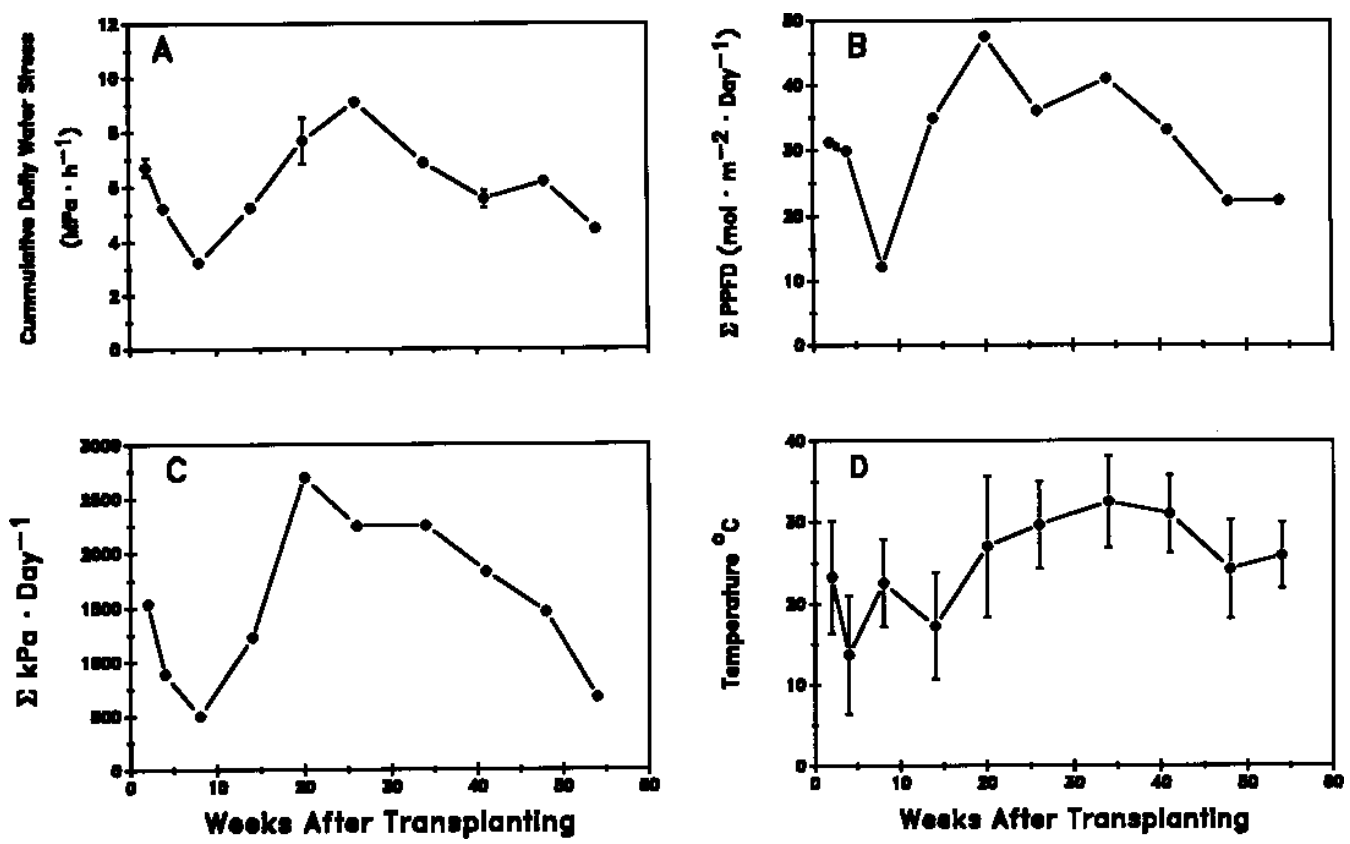

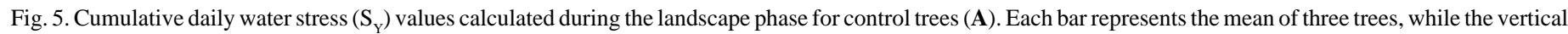

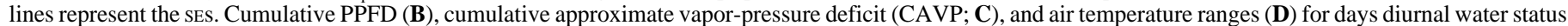

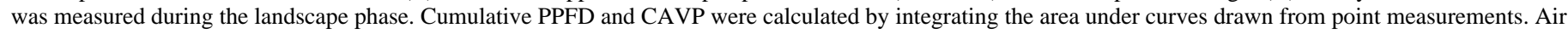
temperature ranges are based on maximum and minimum point measurements recorded about every $2 \mathrm{~h}$ from predawn to after dusk.

Table 2. Correlations of cumulative daily water stress $\left(\mathrm{S}_{\mathrm{Y}}\right)$ with microclimate variables of cumulative approximate vapor-pressure deficit (CAVP), cumulative photosynthetic photon flux density (CPPFD), and mean daylight temperature $\left(\mathrm{T}_{\mathrm{DAY}}\right)$ for the different treatments. Correlations are from measurements taken during the landscape phase, from Nov. 1990 to Nov. 1991.

\begin{tabular}{llll}
\hline \hline Treatment $^{\mathrm{Z}}$ & CAVP & CPPFD & $\mathrm{T}_{\mathrm{DAY}}$ \\
\hline Control & $0.684^{* *}$ & $0.483^{* * *}$ & $0.160^{*}$ \\
Unpruned, 133 liters & $0.432^{* *}$ & $0.323^{* *}$ & $0.126^{*}$ \\
& & & \\
Unpruned, 247 liters & $0.363^{* *}$ & $0.264^{* *}$ & $0.087^{\mathrm{NS}}$ \\
Pruned, 133 liters & $0.605^{* *}$ & $0.520^{* *}$ & $0.089^{\mathrm{NS}}$ \\
Pruned, 247 liters & $0.469^{* *}$ & $0.299^{* *}$ & $0.179^{*}$
\end{tabular}

${ }^{\bar{z}}$ Treatments initiated in the containerization phase. Trees were root pruned or not root pruned before harvest and transplanted into 133- or 247liter polyethylene containers.

Ns,*,**N Nonsignificant or significant at $\alpha \leq 0.05$ or 0.01 , respectively.

water-absorbing root area ratio did not differ among treatments.

In the landscape, in contrast to containerization, increasing container to root-ball volumes decreased tree growth rates (periods 2 and 3; Fig 1). Trees from small containers maintained similar growth rates for 18 months, with root pruning having no effect. However, growth rates declined for unpruned trees in large containers during the landscape phase. Effects of root pruning and container size are not explained by differences in measured tree water status or landscape site soil. A larger percentage of backfill soil was irrigated with small containers, but not so for root-pruned trees from large containers. Thus, low container to root-ball ratios or root pruning maintained growth rates independent of $\psi_{\mathrm{T}}$ measured.

The similarity among treatments for $\psi_{\mathrm{T}}$ comparisons indicate that, under the irrigation regimes used, neither container to rootball volume ratio nor preharvest root pruning affected tree water status. Based on these results, rooting into larger containers seems to produce more rapid canopy re-leaf and perhaps faster market- ability. Root pruning of appropriately sized trees in in-ground fabric containers does not improve survival or postharvest water status and is not justified.

\section{Literature Cited}

Arnold, M.A. and D. K. Struve. 1989. Green ash establishment following transplant. J. Amer. Soc. Hort. Sci. 114:591-595.

Beeson, Jr., R.C. 1991. Irrigation recommendations for establishing landscape trees in Florida. Florida Nurseryman 38(9):31-32, 56.

Beeson, Jr., R.C. 1992. Restricting overhead irrigation to dawn limits growth in container-grown woody ornamentals. HortScience 27:996999.

Beeson, Jr., R.C. 1993. Benefits of progressively increasing container size during nursery production depend on fertilizer regime and species. J. Amer. Soc. Hort. Sci. 118:752-756.

Beeson, Jr., R.C. and E.F. Gilman. 1992. Water stress and osmotic adjustment during post-digging acclimatization of Quercus virginiana produced in fabric containers. J. Environ. Hort. 10:208-214.

Biran, I. and I. Eliassaf. 1980. The effect of container size and aeration conditions on growth of roots and canopy of woody plants. Sci. Hort. 12:385-394.

Castle, W.S. 1983. Antitranspirant and root and canopy pruning effects on mechanically transplanted eight-year-old 'Murcott' citrus trees. J. Amer. Soc. Hort. Sci. 108:981-985.

Geisler, D. and D.C. Ferree. 1984. The influence of root pruning on water relations, net photosynthesis, and growth of young 'Golden Delicious' apple trees. J. Amer. Soc. Hort. Sci. 109:827-831.

Gilman, E.F. and M.E. Kane. 1990. Growth and transplantability of Magnolia grandifloria following root pruning at several growth stages. HortScience 25:74-77.

Grier, C.C. and R.H. Waring. 1974. Conifer foliage mass related to sapwood area. For. Sci. 20:205-209.

Grossnickle, S.C. 1988. Planting stress in newly planted jack pine and white spruce. I. Factors influencing water uptake. Tree Physiol. 4:7183.

Keever, G.J. and G.S. Cobb. 1987. Effects of container volume and fertility rate on growth of two woody ornamentals. HortScience 22:891893.

Kozlowski, T.T. and W.J. Davies. 1975. Control of water loss in shade 
trees. J. Arboricult. 1:81-90.

Maier-Maercher, V. 1979. "Peristomatal transpiration" and stomatal movement: A controversial view. II. Observations of stomatal movement under different conditions of water supply and demand. Z. Pflanzen. 91:157-172.

McCutchan, H. and K.A. Shackel. 1992. Stem-water potential as a sensitive indicator of water stress in prune trees (Pruncus domestica $\mathrm{L}$. cv. French). J. Amer. Soc. Hort. Sci. 117:607-611.

Messina, M.G. and J.E. Duncan. 1993. Irrigation effects on growth and water use of Quercus virginiana (Mill.) on a Texas lignite surface-mined site. J. Agr. Water Mgt. 24:265-280.

Richards, D. and R.N. Rowe. 1977. Effects of root restriction, root pruning and 6-benzlyaminopurine on the growth of peach seedlings. Ann. Bot. 41:729-740.

Snedecor, G.W. and W.G. Cochran. 1980. Statistical methods. 7th ed. Iowa State Univ. Press, Ames. p. 507.

Tenhunen, J.D., O.L. Lange, P.C. Harley, W. Beyschlag, and A. Meyer. 1985. Limitations due to water stress on net photosynthesis of Quercus coccifera in the Portuguese evergreen scrub. Oecologia 67:23-30.

Tschaplinski, T.J. and T.J. Blake. 1985. Effects of root restriction on growth correlations, water relations and senescence of alder seedlings. Physiol. Plant. 64:167-176.

Watson, G. 1985. Tree size affects root regeneration and top growth after transplanting. J. Aboricult. 11:37-40.

Watson, G.W. 1986. Cultural practices can influence root development for better transplanting success. J. Environ. Hort. 4:32-34.

Weber, J.A. and D.M. Gates. 1990. Gas exchange in Quercus rubra (northern red oak) during a drought: Analysis of relations among photosynthesis, transpiration, and leaf conductance. Tree Physiol. 7:215225 .

Whitcomb, C. 1985. Innovations and the nursery industry. J. Environ. Hort. 3:33-38.

Whitehead, D., D.W. Sheriff, and D.H. Greer. 1983. The relationship between stomata conductance, transpiration rate and tracheid structures in Pinus radiata clones grown at different water vapor saturation deficits. Plant Cell Environ. 18:84-87. 